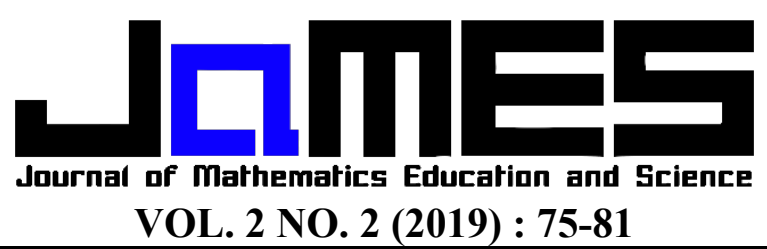

p-ISSN: 2621-1203 | https://doi.org/10.32665/james.v2i2.94

e-ISSN: 2621-1211

\title{
PENGARUH MODEL PEMBELAJARAN MASTER TERHADAP LITERASI MATEMATIS DITINJAU DARI PERBEDAAN GENDER
}

\author{
Ani Sopiani Martinah', Oktavia Hari Kharisma², Sri Purwanti Nasution³, \\ Agus Pahrudin 4 \\ Universitas Islam Negeri Raden Intan Lampung, anisofiani04@gmail.com ${ }^{1}$ \\ Universitas Islam Negeri Raden Intan Lampung, oktaviaharikharismatii@gmail.com² \\ Universitas Islam Negeri Raden Intan Lampung, sripurwanti@yahoo.co.id ${ }^{3}$ \\ Universitas Islam Negeri Raden Intan Lampung, agus.pahrudin@radenintan.ac.id ${ }^{4}$ \\ Received : 20 Mei 2019, Revised : 16 Oktober 2019, Accepted : 17 Oktober 2019 \\ (C) Mathematics Education Unugiri 2019
}

\begin{abstract}
This study aims to determine the effect of MASTER learning models (Motivating, Acquiring, Searching, Triggering, Exhibiting, and Reflecting) on mathematical literacy in terms of gender differences. The method used in this study is Quasy Experimental Design. A random sampling technique took a sample of 60 students. Data collection is carried out with written tests and documentation. The method uses an analysis of variance (ANOVA). Hypothesis testing uses two different path tests of variance analysis in cells. The results showed that there were mixed effects of each learning model on students' mathematical literacy abilities. There was no influence between female and male gender on students' mathematical literacy abilities. There was no interaction between learning models and gender differences in students' mathematical literacy abilities. The teacher must strive to improve the mathematical literacy skills of middle school students so that students are more motivated to learn.
\end{abstract}

Keywords: MASTER Learning Model, Mathematical Literacy, Gender

Abstrak

Penelitian ini bertujuan untuk mengetahui pengaruh model pembelajaran MASTER (Motivating, Acquiring, Searching, Triggering, Exhibiting, and Reflecting) terhadap literasi matematis ditinjau dari perbedaan gender. Metode yang digunakan dalam penelitian ini adalah Quasy Experimental Design. Sampel sebanyak 60 siswa yang diambil dengan teknik random sampling. Pengumpulan data dilaksanakan dengan tes tertulis dan dokumentasi. Teknik analisis data menggunakan analisis variansi (ANOVA). Uji hipotesis menggunakan uji analisis variansi dua jalan sel tak sama. Hasil penelitian menunjukan terdapat pengaruh yang berbeda antara masing-masing model pembelajaran terhadap kemampuan literasi matematis peserta didik. Tidak terdapat pengaruh antara gender perempuan dan laki-laki terhadap kemampuan literasi matematis peserta didik. Tidak terdapat interaksi antara model pembelajaran dan perbedaan gender terhadap kemampuan literasi matematis peserta didik. Untuk meningkatkan kemampuan literasi matematis peserta didik SMP, pendidik harus berupaya agar peserta didik lebih termotivasi untuk belajar.

\section{Kata kunci: Model Pembelajaran MASTER, Literasi Matematis, Gender}

\section{Pendahuluan}

Model pembelajaran yang diharapkan mampu meningkatkan motivasi peserta didik, melatih keterampilan-keterampilan peserta didik dan membentuk kemandirian belajar peserta didik adalah model pembelajaran
MASTER (Motivating, Acquiring, Searching, Triggering, Exhibiting, and Reflecting) [1]. Model pembelajaran MASTER merupakan suatu langkah yang diterapkan dalam pembelajaran Accelerated Learning yang diterapkan pada kegiatan pembelajaran dengan 
tujuan kegiatan pembelajaran dapat terasa menyenangkan bagi peserta didik [2].

Model pembelajaran MASTER menuntut peserta didik untuk aktif dalam mencari dan mengumpulkan informasi selama proses pembelajaran berlangsung, sehingga pengetahuan yang diperoleh selama proses pembelajaran berlangsung tidak hanya dari pendidik, melainkan dapat diperoleh dari teman satu kelasnya. Model pembelajaran MASTER merupakan model pembelajaran yang terdiri dari enam langkah. Enam langkah dalam model pembelajaran MASTER memberi kebebasan peserta didik dalam belajar sehingga peserta didik menikmati perasaan yang nyaman tanpa keterpaksaan dan menjalankan kegiatan pembelajaran dengan puncak kemampuannya.

Model pembelajaran MASTER memberi kebebasan peserta didik dalam bepikir sesuai kemampuannya dan membuat peserta didik dapat menciptakan suasana yang relaks, menjamin bahwa subjek pelajaran adalah relevan, menjamin bahwa belajar secara emosional adalah positif, melibatkan secara sadar semua indera dan juga pikiran otak kiri dan kanan, menantang otak untuk dapat berpikir jauh ke depan dan mengeksplorasi apa yang sedang dipelajari.

Kenyataannya yang terjadi saat proses pembelajaran berlangsung, guru masih menggunakan metode pembelajarannya sendiri seperti ceramah, mengerjakan soal, dan memberikan tugas. Secara tidak sadar hal ini dapat menimbulkan kebosanan dan peserta didik tidak dapat memahami pelajaran matematika. Guru hendaknya dapat menggunakan model pembelajaran yang dapat membuat suasana menjadi menyenangkan seperti model pembelajaran MASTER, sehingga peserta didik dapat terlibat penuh dalam pembelajaran matematika dan termotivasi dalam belajar matematika.

Model pembelajaran MASTER menuntun peserta didik untuk mengetahui bagaimana cara belajar dan cara berfikir melalui 6 langkah yang dikenal dengan istilah MASTER. Model pembelajaran MASTER diterapkan bertujuan dapat mengembangkan daya ingat dan dapat menyerap informasi-informasi yang diperoleh peserta didik, termotivasi dan aktif dalam pembelajaran, meningkatkan kemampuan penalaran peserta didik dan dapat meningkatkan kemampuan literasi matematis peserta didik.

Kusumah mengemukakan bahwa yang berkaitan dengan literasi adalah keterampilan komunikasi tertulis yaitu kemampuan menulis dan kemampuan membaca. Kemampuan literasi matematis merupakan kemampuan individu dalam merumuskan, menggunakan, menafsirkan matematika diberbagai konteks [3]. Kemampuan literasi matematis penting untuk dikembangkan dan dibangun dalam diri peserta didik untuk menunjukkan kemampuan peserta didik dalam merumuskan, menggunakan, menafsirkan matematika dalam berbagai konteks termasuk bernalar secara sistematis. Kemampuan literasi matematis penting untuk diperhatikan, melalui literasi matematis peserta didik dapat bernalar secara matematis yang dapat terjadi dalam proses pembelajaran.

Kemampuan literasi matematis membantu seseorang dalam memilih keputusan yang tepat. Seseorang yang telah mampu untuk merumuskan, mempekerjakan dan menafsirkan matematika dalam berbagai konteks maka peserta didik akan mendapatkan kemudahan dalam pengambilan keputusan, serta telah terlatih untuk berfikir dengan pola pikir tingkat tinggi, peserta didik saat ini untuk kemampuan literasi matematisnya dapat digolongkan masih rendah. Kemampuan literasi pada peserta didik juga berbeda-beda, salah satu faktor yang dapat mempengaruhi kemampuan literasi matematis adalah perbedaan gender.

Menurut American Psychological Association, berdasarkan analisis terbaru dari penelitian internasional untuk kemampuan perempuan di seluruh dunia dalam matematika tidak lebih buruk daripada kemampuan laki-laki meskipun laki-laki memiliki kepercayaan diri yang lebih dari perempuan dalam matematika [4]. Gender merupakan sifat dan perilaku atau pembagian peran sebagai laki-laki dan perempuan [5]. 
Rendahnya kemampuan literasi peserta didik baik laki-laki atau perempuan terlihat pada saat peserta didik tidak mampu menyelesaikan soal-soal yang diberikan dengan benar dan tepat. Peserta didik dengan kondisi seperti yang telah dijelaskan jika tidak ditanggapi lebih lanjut akan mengakibatkan peserta didik tidak mampu memahami pelajaran matematika untuk ke depannya. Literasi matematis mrupakan kemampuan peserta didik yang menjadi tujuan utama pada pembelajaran matematika [6]. Memperhatikan pentingnya peserta didik mempunyai kemampuan literasi matematis pada kegiatan belajar matematika untuk pendidik harus ada usaha untuk meningkatkannya.

Berdasarkan deskripsi permasalahan di atas, penulis tertarik untuk menerapkan model pembelajaran MASTER dengan harapan dapat memberikan proses pembelajaran yang menyenangkan sehingga dapat meningkatkan kemampuan literasi matematis peserta didik baik laki-laki maupun perempuan, maka judul penelitian ini tentang Pengaruh Model Pembelajaran MASTER (Motivating, Acquiring, Searching, Triggering, Exhibiting, and Reflecting) Terhadap Literasi Matematis Ditinjau dari Perbedaan Gender.

\section{Metode Penelitian}

Metode penelitian secara umum adalah suatu cara yang digunakan untuk mendapatkan data dengan tujuan dan kegunaan tertentu. Penelitian ini menggunakan jenis penelitian yaitu penelitian eksperimen. Jenis eksperimen yang digunakan adalah Quasy Experimental Design. Desain ini mempunyai kelompok kontrol namun tidak sepenuhnya berfungsi mengontrol variabel-variabel luar yang mempengaruhi pelaksanaan eksperimen [7].

Desain yang digunakan dalam penelitian ini adalah desain faktorial $2 \times 2$ dengan mengambil dua kelas dari populasi yaitu kelas eksperimen dan kelas kontrol. Kelas eksperimen diberi perlakuan menggunakan model pembelajaran MASTER (Motivating, Acquiring, Searching, Triggering, Exhibiting, and Reflecting) dan kelas kontrol diberi perlakukan menggunakan metode ceramah. Ditinjau dari data dan analisis data penelitian ini merupakan penelitian kuantitatif. Karena data yang dikumpulkan berupa angka dan dalam proses pengolahan data dan pengujian hipotesis. Penelitian kuantitatif cocok digunakan dalam penelitian ini, karena sesuai dengan maksud dari penelitian, yaitu untuk memperoleh data kemampuan literasi matematis paeserta didik laki-laki dan perempuan pada peserta didik kelas VII di SMP N 16 Bandar Lampung. Untuk mengetahui pengaruh variabel data, maka teknik analisis data menggunakan analisis variansi dua jalan.

Variabel yang digunakan dalam penelitian adalah variabel bebas dan variabel terikat. Variabel bebas yaitu variabel yang dapat mempengaruhi atau yang menyebabkan perubahan atau yang menimbulkan variabel terikat (dependent variable). Variabel bebas biasa disebut dengan variabel stimulus, preiktor, antecendent [8]. Variabel bebas merupakan variabel yang mempengaruhi kemampuan peserta didik biasa disebut dengan variabel X. Adapun dalam penelitian ini yang menjadi variabel bebas (X) yaitu model pembelajaran MASTER $\left(\mathrm{X}_{1}\right)$ dan perbedaan gender $\left(\mathrm{X}_{2}\right)$.

Variabel terikat merupakan variabel yang dipengaruhi atau yang menjadi akibat, karena adanya variabel bebas (independent) [9]. Variabel terikat biasa disebut sebagai variabel output, kriteria, konsekuen. Variabel terikat merupakan variabel yang dipengaruhi atau aspek yang dukur dalam penelitian yang biasa disebut dengan variabel $Y$ [10]. Penelitian ini yang menjadi variabel terikat $(\mathrm{Y})$ ialah literasi matematis. Intrument pada penelitian ini menggunakan soal tes kemampuan literasi matematis.

\section{Hasil dan Pembahasan}

Penelitian ini dari populasi yang bejumlah 6 kelas diambil dua sampel kelas yaitu kelas VII B dengan jumlah 30 peserta didik sebagai kelas eksperimen dengan perlakuan model pembelajaran MASTER dan kelas VII D dengan jumlah 30 peserta didik sebagai kelas kontrol dengan perlakuan menggunakan metode ceramah. Pengambilan sampel 
dilakukan dengan cara acak kelas. Setiap pertemuan untuk kelas eksperimen dibentuk kelompok dalam proses pembelajaran dan diberikan Lembar Kerja Kelompok (LKK) untuk setiap kelompok. Berikut ini adalah untuk tahapan proses pembelajaran menggunakan model pembelajaran MASTER di kelas eksperimen.

Tahap peratama Motivating your mind, peserta didik diberikan motivasi diawal pembelajaran yang bertujuan dapat meningkatkan motivasi peserta didik dalam belajar. Dan setelah diberikan motivasi peserta didik dibentuk kelompok yang beranggotakan 5-6 orang. Tahap kedua Acquiring the information, pada tahap ini peserta didik diberikan materi tentang perbandingan guna memperoleh informasi, dan diberikan kesempatan untuk bertanya jika belum memahami materi yang diberikan.

Tahap ketiga Searching out the meaning, setiap kelompok diberikan Lembar Kerja Kelompok (LKK). Tahap ini setiap kelompok mengerjakan LKK dengan tujuan melatih peserta didik menggali informasi yang telah didapatkan. Tahap keempat Triggering the memory, pada tahapan ini setiap kelompok membahas soal yang telah dikerjakan dan menulis soal jawaban di buku masing-masing guna memicu ingatan peserta didik dan dapat menyimpan informasi yang telah diperoleh.

Tahap kelima Exhibiting what you know, pada tahap ini setiap kelompok mempresentasikan hasil pekerjaan mereka di depan kelas. Tahap keenam Reflecting how you're learned, pada tahap ini guru mengajak peserta didik untuk mengevaluasi, menganalisa masukan, tanggapan dan koreksi dari guru terkait pembelajaran yang telah berlangsung tentang materi perbandingan.

Pembelajaran pada kelas kontrol yang menerapkan metode ceramah yaitu model pembelajaran yang berpusat pada pendidik dan materi yang diberikan untuk kelas kontrol adalah materi perbandingan. Pada proses pembelajaran berlangsung pendidik memberikan materi dengan metode ceramah yaitu pendidik menjelaskan dan peserta didik mendengarkan dan meperhatikan materi yang dijelaskan pendidik serta mencatatnya, selanjutnya pendidik memberi kesempatan peserta didik untuk bertanya.

Tanya jawab dilakukan bertujuan untuk mengetahui tentang materi yang belum dipahami. Setelah pendidik selesai menjelaskan materi pendidik memberikan tugas berupa soal. Penugasan dilakukan dengan tujuan untuk mengetahui bahwa peserta didik sudah memahami materi yang diberikan dan dapat mnyelesaiakan tugas yang diberikan. Adapun penugasan untuk peserta didik diberikan setelah selesai pembelajaran, yaitu setiap peserta didik diberikan lembar soal kemudian menyelesaikannya.

Uraian di atas terlihat bahwa proses pembelajaran pada kelas eksperimen dengan model pembelajaran MASTER peserta didik terlihat lebih berantusias dalam belajar karena proses pembelajaran dilakukan dengan berkelompok dan menggunakan LKK. Sedangkan pada kelas kontrol dengan pembelajaran konvensional peserta didik kurang berantusias dalam belajar karena peserta didik sudah terbiasa dengan pembelajaran tersebut.

Tabel 1. Deskripsi Data Skor Amatan Soal Tes Kemampuan Literasi Matematis

\begin{tabular}{|c|c|c|c|}
\hline $\begin{array}{c}\text { Model } \\
\text { Pembelajaran }\end{array}$ & Gender & $\begin{array}{c}\text { Ukuran } \\
\text { Deskripsi }\end{array}$ & Skor \\
\hline \multirow{10}{*}{ MASTER } & \multirow{5}{*}{$\mathrm{L}$} & Mean & 79 \\
\hline & & Modus & 89 \\
\hline & & Median & 83 \\
\hline & & Skor Maks & 89 \\
\hline & & Skor Min & 44 \\
\hline & \multirow{5}{*}{$\mathrm{P}$} & Mean & 82,3 \\
\hline & & Modus & 78 \\
\hline & & Median & 83 \\
\hline & & Skor Maks & 94 \\
\hline & & Skor Min & 61 \\
\hline \multirow{10}{*}{ Konvensional } & \multirow{5}{*}{$\mathrm{L}$} & Mean & 67,7 \\
\hline & & Modus & 72 \\
\hline & & Median & 69,5 \\
\hline & & Skor Maks & 78 \\
\hline & & Skor Min & 50 \\
\hline & \multirow{5}{*}{$\mathrm{P}$} & Mean & 68,4 \\
\hline & & Modus & 67 \\
\hline & & Median & 67 \\
\hline & & Skor Maks & 83 \\
\hline & & Skor Min & 83 \\
\hline
\end{tabular}

http://journal.unugiri.ac.id/index.php?journal=JaMES 


\subsection{Deskripsi data amatan}

Pengambilan data dilakukan setelah proses pembelajaran pada materi perbandingan selesai. Setelah data dari setiap variabel terkumpul, maka selanjutnya digunakan untuk pengujian hipotesis penelitian. Data yang terkumpul dapat dicari nilai tertinggi ( $\left.X_{\text {maks }}\right)$ dan nilai terendah $\left(\mathrm{X}_{\min }\right)$ kemudian dicari ukuran tendensi setaranya yang meliputi rataan $(\bar{X})$, median $\left(\mathrm{M}_{\mathrm{e}}\right)$, modus $\left(\mathrm{M}_{\mathrm{o}}\right)$ pada kelas ekperimen dan kelas kontrol yang dapat dilihat pada Tabel 1 .

\subsection{Uji Prasyarat}

a. Uji Normalitas Berdasarkan Kelas

Uji analisis dengan menggunakan liliefors terhadap hasil tes kemampuan literasi matematis peserta didik dilakukan pada masingmasing kelompok data yaitu kelas eksperimen dan kelas kontrol. Data uji normalitas kelas tersebut disajikan pada tabel 2 berikut :

Tabel 2. Uji Normalitas Berdasarkan kelas

\begin{tabular}{cccc}
\hline $\begin{array}{c}\text { Kelas/ } \\
\text { Gender }\end{array}$ & $\mathbf{L}_{\text {hit }}$ & $\mathbf{L}_{\text {tab }}$ & $\begin{array}{c}\text { Keputusan } \\
\text { Uji }\end{array}$ \\
\hline \multicolumn{4}{c}{ Eksperimen } \\
\hline $\mathrm{P}$ & 0,113 & 0,2071 & $\mathrm{H}_{0}$ diterima \\
\hline $\mathrm{L}$ & 0,205 & 0,2337 & $\mathrm{H}_{0}$ diterima \\
\hline \multicolumn{4}{c}{ Kontrol } \\
\hline $\mathrm{P}$ & 0,154 & 0,2018 & $\mathrm{H}_{0}$ diterima \\
\hline $\mathrm{L}$ & 0,137 & 0,2426 & $\mathrm{H}_{0}$ diterima \\
\hline
\end{tabular}

Kesimpulan dari hasil uji normalitas kemampuan literasi matematis berdasarkan kelas yaitu dengan taraf signifikan 5\% nilai $L_{\text {hitung }} \leq \mathrm{L}_{\text {tabel }}$ sehingga $\mathrm{H}_{0}$ untuk setiap kelas diterima atau dapat disimpulkan bahwa data berdistribusi normal.

\section{b. Uji Homogenitas Berdasarkan Kelas}

Uji homogenitas digunakan untuk mengetahui apakah sampel memiliki variansivariansi yang sama atau tidak. Uji homogenitas dilakukan antara kelas eksperimen dan kelas kontrol. Uji homogenitas dilakukan setelah diberikan perlakuan pada setip kelas. Uji homogenitas dilakukan dengan menggunakan uji Barlett. Hasil Uji homogenitas data kemampuan literasi matematis peserta didik dengan taraf signifikan 5\% diperoleh $x_{\text {hitung }}^{2}=$ 0,041 dan $x_{\text {tabel }}^{2}=3,481$ dari perhitungan uji homogen kemampuan literasi matematis berdasarkan kelas. Berdasarkan hasil perhitungan tersebut menunjukkan bahwa $x_{\text {hitung }}^{2} \leq x_{\text {tabel }}^{2}$, maka dapat disimpulkan bahwa $\mathrm{H}_{0}$ diterima atau dapat disimpulkan bahwa data tersebut berasal dari populasi yang homogen yang artinya kelompok tersebut memiliki variansi (kemampuan) yang sama.

\section{c. Uji Normalitas Berdasarkan Gender}

Uji analisis dengan menggunakan liliefors terhadap hasil tes kemampuan literasi matematis peserta didik dilakukan pada masingmasing kelompok data berdasarkan gender yaitu perempuan dan laki-laki. Data uji normalitas tersebut disajikan pada tabel berikut:

Tabel 3. Uji Normalitas Berdasarkan Gender

\begin{tabular}{cccc}
\hline Kelas & $\mathbf{L}_{\text {hit }}$ & $\mathbf{L}_{\text {tab }}$ & $\begin{array}{c}\text { Keputusan } \\
\text { Uji }\end{array}$ \\
\hline $\begin{array}{c}\text { Eksperimen } \\
\text { Kontrol }\end{array}$ & 0,144 & 0,159 & $\mathrm{H}_{0}$ diterima \\
\hline
\end{tabular}

Kesimpulan dari hasil uji normalitas kemampuan literasi matematis berdasarkan perbedaan gender (perempuan dan laki-laki) yaitu dengan taraf signifikan $5 \%$ nilai $L_{\text {hitung }} \leq$ $\mathrm{L}_{\text {tabel }}$ sehingga $\mathrm{H}_{0}$ untuk setiap gender diterima atau dapat disimpulkan bahwa data berdistribusi normal.

\section{d. Uji Homogenitas Berdasarkan Gender}

Uji homogenitas dilakukan berdasarkan gender antara kelas eksperimen (perempuan dan laki-laki) dan kelas kontrol (perempuan dan laki-laki). Uji homogenitas dilakukan dengan menggunakan uji Barlett. Hasil Uji homogenitas data kemampuan literasi matematis peserta didik dengan taraf signifikan $5 \%$ diperoleh $x_{\text {hitung }}^{2}=3,550$ dan $x_{\text {tabel }}^{2}=$ 7,815 dari perhitungan uji homogen kemampuan literasi matematis berdasarkan gender antara kelas eksperimen dan kelas kontrol. Berdasarkan hasil perhitungan tersebut menunjukkan bahwa $x_{\text {hitung }}^{2} \leq x_{\text {tabel }}^{2}$, maka dapat disimpulkan bahwa $\mathrm{H}_{0}$ diterima atau dapat 
disimpulkan bahwa data tersebut berasal dari populasi yang homogen yang artinya kelompok tersebut memiliki variansi (kemampuan) yang sama.

\subsection{Uji Hipotesis}

Uji hipotesis dalam penelitian menggunakan analisis variansi dua jalan sel tak sama. Uji hipotesis ini digunakan karena terdapat dua variabel bebas yaitu model pembelajaran MASTER dan gender, dan satu variabel terikat yaitu literasi matematis. Hasil analisis variansi pada tabel analisis variansi dua jalan sel tak sama di atas menunjukkan bahwa hasil analisis variansi berdasarkan model pembelajaran diperoleh $F_{\text {hitung }}=22,555$ dan $\mathrm{F}_{\text {tabel }}=4,013$. Berdasarkan perhitungan analis data pada tabel terlihat bahwa $\mathrm{db}=\left\{\mathrm{F}_{\text {hitung }} \mid\right.$ $\left.\mathrm{F}_{0.05 ; 1 ; 56}>4,013\right\}$, sehingga dapat disimpulkan bahwa $\mathrm{H}_{0}$ ditolak, artinya terdapat pengaruh model pembelajaran MASTER dan metode ceramah terhadap kemampuan literasi matematis peserta didik. Hasil analisis variansi pada model pembelajaran dapat dilihat peserta didik dengan menggunakan model pembelajaran MASTER mendapatkan nilai ratarata yang lebih tinggi darapada peserta didik kelas kontrol, maka model pembelajaran MASTER lebih baik untuk diterapkan daripada menggunakan metode ceramah.

Hasil analisis variansi berdasarkan gender diperoleh $\mathrm{F}_{\text {hitung }}=0,336$ dan $\mathrm{F}_{\text {tabel }}=$ 4,013. Berdasarkan perhitungan analis data pada tabel terlihat bahwa $\mathrm{db}=\left\{\mathrm{F}_{\text {hitung }} \mid \mathrm{F}_{0.05 ; 1 ; 56}\right.$ $<4,013\}$, sehingga dapat disimpulkan bahwa $\mathrm{H}_{0}$ diterima, artinya tidak terdapat pengaruh antara gender perempuan dan laki-laki terhadap kemampuan literasi matematis peserta didik. Hasil analsis variansi berdasarkan interaksi antara model pembelajaran dan gender diperoleh $\mathrm{F}_{\text {hitung }}=0,439$ dan $\mathrm{F}_{\text {tabel }}=4,013$. Berdasarkan perhitungan analis data pada tabel terlihat bahwa $\mathrm{db}=\left\{\mathrm{F}_{\text {hitung }} \mid \mathrm{F}_{0.05 ; 1 ; 56}<4,013\right\}$, sehingga dapat disimpulkan bahwa $\mathrm{H}_{0}$ diterima, artinya tidak terdapat interaksi antara model pembelajaran dan perbedaan gender terhadap kemampuan literasi matematis peserta didik.

\section{Kesimpulan}

Berdasarkan analisis data dan pengujian hipotesis yang telah diakukan, maka dapat disimpulkam bahwa yang pertama terdapat pengaruh model pembelajaran MASTER (Motivating, Acquiring, Seraching, Triggering, Exhibiting, and Reflecting) terhadap literasi matematis peserta didik. Kedua tidak terdapat pengaruh yang berbeda pada kategori perbedaan gender perempuan dan laki-laki terhadap literasi matematis peserta didik. Ketiga tidak terdapat interaksi antara model pembelajaran MASTER (Motivating, Acquiring, Seraching, Triggering, Exhibiting, and Reflecting dengan perbedaan gender terhadap literasi matematis peserta didik.

\section{Referensi}

[1] Santoso, N., St. B. Waluya, dan S. Yarno, Kemampuan Pemecahan Masalah Pada Pembelajaran Matematika Dengan Strategi MASTER dan Penerapan Scaffolding, UNNES Journal of Mathematics Education Research, Universitas Negeri Semarang, (2013) 70.

[2] Rose, C. dan M. J. Nicholl, Accelerated Learning For The 21st Century Cara Belajar Cepat Abad XXI. Bandung: Nuansa, (2009).

[3] Khoirudin, A., R. D. Setyawati, dan F. Nursyahida, Profil Kemampuan Literasi Matematika Siswa Berkemampuan Matematis Rendah Dalam Menyelesaikan soal Berbentuk PISA, Aksioma Universitas PGRI Semarang, (2017) p. 34

[4] Fitriyah, I. dan I. Setianingsih, Metakognisi Siswa SMP Dalam Menyelesaikan Soal Cerita Ditinjau Dari Kemampuan Matematika dan Gender, Jurnal Ilmiah Pendidikan Matematika, UNESA, vol. 3 no. 3 (2014) p.122

[5] Azizah S., Buku Saku Konstektualisasi Gender Islam dan Budaya. Makasar: UIN ALAUDDIN, (2016).

[6] Abidin, Y., T. Mulyani, dan H. Yunansah, Pembelajaran Literasi. Bandung: Bumi Aksara, (2017). 
[7] Sugiyono, Metode Penelitian Pendekatan Kuantitaif, Kualitatif, dan $R \& D$, Bandung: Alfabeta, (2013).

[8] Martono, N., Metode Penelitian Kuantitatif Analisis Isi dan Analisis Data Sekunder, Jakarta : $\quad$ PT RAJAGRAFINDO PERSADA, (2010).
[9] Maolani, A. dan Rukaesih, Metode Penelitian Pendidikan. Jakarta: Rajawali Pers, (2016)

[10] Budiyono, Statistika Untuk Penelitian. Surakarta: UPT Penerbitan dan Pencetakan UNS, (2009). 